\title{
Notes
}

\section{Regulatory Analyses and Judicial Review of Informal Rulemaking}

In recent years, each branch of the federal government has attempted or considered attempts to force internal management standards upon administrative agencies in order to limit the agencies' rulemaking discretion. Congress is once again considering legislation ${ }^{1}$ to reiterate and extend the requirements of recent Executive Orders that establish such standards for the promulgation of major rules. ${ }^{2}$ Courts have remanded agency action that fails to comply with a similar management model. ${ }^{3}$ None of these attempts, however, has been wholly or even largely successful.

This Note argues for a coordination of efforts through legislative endorsement of judicial review of agency internal management requirements. Scant attention has been paid to this idea; within the executive and legislative branches, it has been opposed because of fears of judicial incompetence and judicially caused delay. ${ }^{4}$ This Note suggests that objections to judicial review are based on a failure to perceive the similarities between standards of judicial review already applied and internal management standards enacted or being considered for enactment. It concludes that legislative endorsement of judicial review of internal management standards can help ensure that the internal management model is effectively implemented without creating substantial delay.

\section{Checking Agency Discretion Through Internal Management Standards}

Proposals for internal management standards are the product of recent reexaminations of the efficacy and legitimacy of federal administrative agencies. ${ }^{5}$ During the first six decades of this century, agencies were sub-

1. See infra pp. 748-52.

2. See infra pp. 746-49.

3. See infra pp. 744-46.

4. See infra pp. 761-63.

5. See Stewart, The Reformation of American Administrative Law, 88 HARV. L. REV. 1667, 1669-88, 1711-1760 (1975) (summarizing and analyzing criticisms of agency performance and several proposed solutions). 
ject to few checks on their authority ${ }^{6}$ The paucity of controls was justified initially on the basis that agencies did nothing more than follow the statutory mandates of Congress; that is, they had little discretion to check. ${ }^{7}$ Confronted during the 1930's with broad congressional mandates, this simple justification of agency independence gave way to the "expertise" justification, ${ }^{8}$ which held that the apparent discretion was strictly circumscribed by the rigors of professionalism. Congress had to give broad mandates to agencies because intelligent regulation required the development of expertise concerning the problem to be regulated and the flexibility to respond to resulting changes in the understanding of the problem. But administrators, being professionals, were constrained by their own expertise: professionalism would lead them ineluctably to the solutions that contemporaneous knowledge demonstrated were best.

Studies of agencies during the last twenty years have cast considerable doubt on this model of administrative behavior. ${ }^{9}$ Administrative agencies do not always act as expert implementers of given norms, adapting the method of implementation to changing circumstances, but often must balance competing values or choose among them. ${ }^{10}$ Furthermore, instead of being responsive to new fact, policy or value arguments, agencies have tended over time to become institutionally committed to particular viewpoints or regulatory approaches. They resist challenges to such entrenched positions by making outside participation in agency decisionmaking difficult, by failing to respond to new facts and policy arguments, and by us-

6. Only the judiciary provided a routine means of checking agencies, and its checks were very weak. See, e.g., Pacific States Box \& Basket Co. v. White, 296 U.S. 176, 186 (1935) (presuming existence of facts necessary to justify regulation of containers of agricultural products and refusing to examine closely purported policy ends of the regulation); Superior Oil Co. v. Federal Power Comm'n, 322 F.2d 601, 619 (9th Cir. 1963), cert. denied, 377 U.S. 922 (1964) (upholding Federal Power Commission's summary rejection of independent natural gas producer's rate filings based upon commission expertise developed through studies and experience).

7. See Reagan v. Farmer's Loan \& Trust Co., 154 U.S. 362, 394 (1894) (railroad rate commission with broad powers is "merely an administrative board . . . carrying into effect the will of the State"); Berle, The Expansion of American Administrative Law, 30 HARV. L. REV. 430, 430-31 (1917).

8. See, e.g., Phelps Dodge Corp. v. NLRB, 313 U.S. 177, 194 (1941) ("Because the relation of remedy to policy is peculiarly a matter for administrative competence, courts . . . must guard against the danger of sliding unconsciously from the narrow confines of law into the more spacious domain of policy. . . . [The National Labor Relations Act] entrusts to an expert agency the maintenance and promotion of industrial peace."); J. LANDIS, THE ADMINISTRATIVE PROCESS 10-17, 98-99 (1938); Freedman, Crisis and Legitimacy in the Administrative Process, 27 STAN. L. REV. 1041, 1058 (1975); Stewart, supra note 5, at 1678 .

9. See generally Stewart, supra note 5, at 1682-88, 1711-16.

10. See SENATE COMM. ON GOVERNMENTAL AFFaiRS, STUdY ON Federal REgulation, 95th Cong., 1st Sess., pt. 3, at 4 (1977) [hereinafter cited as STUDY ON FEDERAL REgulation]; Bazelon, Coping with Technology Through the Legal Process, 62 CORNELl L. REV. 817, 819 (1977); Freedman, supra note 8, at 1054, 1060; Bruff \& Gellhorn, Congressional Control of Administrative Regulation: A Study of Legislative Vetoes, 90 HARV. L. REV. 1369, 1372, 1427 (1977). 
ing the claim of expertise to shield their decisions from scrutiny. ${ }^{11}$

These descriptions of agency behavior suggest serious problems of legitimacy and efficacy. To the extent that public policy reflecting important value choices is made by unchecked officials with only minimal and perhaps one-sided public input, ideals of representative democracy are threatened..$^{12}$ To the extent that agencies do not develop and utilize expertise, their efficacy is subject to doubt. ${ }^{13}$

The recognition of these problems has stimulated substantial thought concerning reform of the administrative process. One type of proposed reform would increase direct control over the substance of agency policies. Specific techniques that have been advocated include: increasing legislative control through revival of the non-delegation doctrine, ${ }^{14}$ or the use of legislative vetoes ${ }^{15}$ or sunset legislation; ${ }^{16}$ increasing presidential power to review, modify, and reverse agency policy; ${ }^{17}$ and increasing judicial scrutiny by removing presumptions of validity accorded agency determinations of fact and law. ${ }^{18}$ Several of these suggestions are of questionable consistutionality. ${ }^{19}$ All have been attacked as unworkable or inefficacious. ${ }^{20}$

11. One form of this theory suggests that agencies are "captured," through bribery, by the interests they regulate. Other forms of the theory emphasize the agency's limited sources of information and other resources, as well as the structure of risks and rewards facing the bureaucrat. See STUDY ON FEDERAL REGULATION, supra note 10, pt. 3, at 1-5; Freedman, supra note 8, at 1053-56; Stewart, supra note 5 , at $1682,1684-86$.

12. See Freedman, supra note 8, at 1044, 1055-56; McGowan, Congress, Court and Control of Delegated Power, 77 ColuM. L. REv. 1119, 1130-31 (1977); Stewart, supra note 5, at 1672, 1676, 1684-87.

13. See Weyerhaeuser Co. v. Costle, 590 F.2d 1011, 1030 (D.C. Cir. 1978) (remanding regulation limiting certain effluent discharges of pulp and paper mills when regulation was based on computations conceded to be in error); Getman \& Goldberg, The Myth of Labor Board Expertise, $39 \mathrm{U}$. CHI. L. REV. 681 (1972).

14. See, e.g., Industrial Union Dep't, AFL-GIO v. American Petroleum Inst., 448 U.S. 607, 672 76 (1980) (Rehnquist, J., concurring); T. LOWI, THE END OF LIBERALISM 297-98 (1969); Wright, Book Review, 81 YALE L.J. 575, 586-87 (1972) (reviewing K. DAVIS, DISCRETIONARY JUSTICE: A PRELIMINARY INQUIRY (1969)). See generally A.L.A. Schecter Poultry Corp. v. United States, 295 U.S. 495 (1935) (striking down $\S 3$ of National Industrial Recovery Act as unconstitutional delegation of legislative power).

15. See, e.g., S. 104, 96th Cong., 1st Sess., 125 CoNG. REC. S304 (1979); J. MASHAW \& R. MERRILl, INTRODUCTION TO THE AMERICAN PUBLIC LAW SYSTEM 1-2 (Supp. 1980) (describing increased frequency of enactment of legislative veto provisions); Abourezk, The Congressional Veto: $A$ Contemporary Response to Executive Encroachment on Legislative Prerogatives, 52 IND. L.J. 323 (1977).

16. See, e.g., H.R. 2, 96th Cong., 1st Sess. (1979) (proposing general sunset law); S. 2, 96th Cong., 1st Sess., 125 CONG. REC. S64 (1979) (same); S. REP. NO. 981, 95th Cong., 2d Sess. (1978) ; Adams, Sunset: A Proposal for Accountable Government, 28 AD. L. REV. 511 (1976).

17. See S. 1545, 96th Cong., 1st Sess., 125 CONG. REC. S9898 (1979); Cutler \& Johnson, Regulation and the Political Process, 84 YALE L.J. 1395 (1975).

18. This proposal, commonly referred to as the "Bumpers Amendment" or the "Bumpers Proposal" after its chief proponent, Senator Bumpers, has been introduced into Congress in each of the last few Congresses. See, e.g., S. 1477, 96th Cong., 1st Sess., 125 Cong. REC. S12,145 (1979) (floor amendment offered by Senator Bumpers); S. 86, 95th Cong., 1st Sess., 123 CONG. REC. 639 (1977).

19. Substantial doubt exists as to the constitutionality of the legislative veto. See, e.g., President's Message to Congress on Legislative Vetoes, 14 WEEKLY COMP. PRES. DOC. 1146, 1147 (June 26, 
A second type of proposed reform would restructure the process of agency rulemaking by requiring agencies to open themselves to public scrutiny, encourage public participation, and explain the bases of and reasoning behind their decisions. Openness and explication, it is contended, will inhibit irrationality and arbitrariness. ${ }^{21}$ Resulting oversight of the agency's factual and normative determinations by Congress, experts in various disciplines, and the public ${ }^{22}$ will facilitate further testing of factual determinations, and intelligent public debate over value choices, and thus, perhaps, will diminish public cynicism and distrust of government. ${ }^{23}$ Increasing participation will create a surrogate political process, thus increasing the legitimacy of agency action. ${ }^{24}$ Furthermore, by increasing the information and value perspectives available to the agency, it will minimize the chance of unconscious policy bias. ${ }^{25}$ When combined with the requirement of explication, it may help limit conscious agency bias by permitting agencies to adopt only those policies for which they can give a reasoned response to objections raised by participants. ${ }^{26}$

This second type of reform, the imposition of internal management standards, ${ }^{27}$ thus attacks the problems of rule by the so-called "fourth

1978); Bruff \& Gellhorn, supra note 10; McGowan, supra note 12, at 1132-62; Stewart, Constitutionality of the Legislative Veto, 13 HARV. J. LEGIS. 593 (1976). But see Atkins v. United States, 556 F.2d 1028, 1063 (Ct. Cl. 1977), cert. denied, 434 U.S. 1009 (1978) (per curiam) (plurality opinion upholding one-house veto).

Proposals to increase Presidential power to review agency action also raise questions of constitutionality. See McGowan, supra note 12 , at $1168-71$.

20. See, e.g., Bazelon, supra note 10, at 829-30 (discussing impossibility of legislature providing sufficient check); Bruff \& Gellhorn, supra note 10 (legislative veto); DeMuth, The White House Review Programs, Regulation, Jan.-Feb. 1980, at 13, 25 (Cutler and Johnson proposal); McGowan, supra note 12, at 1132-62,1165-68, 1170-71 (legislative veto, Cutler and Johnson proposal, and Bumpers Amendment); Stewart, supra note 5, at 1696-97 (non-delegation doctrine).

21. See STUDY ON FEDERAL REGULATION, supra note 10, pt. 3, at 3-5; Bazelon, supra note 10, at 825; Friendly, "Some Kind of Hearing," 123 U. PA. L. REv. 1267, 1292 (1975); Stewart, supra note 5 , at $1679-80,1702$.

22. See Bazelon, supra note 10 , at 823 ; Stewart, supra note 5 , at 1701 .

23. See Bazelon, supra note 10, at 823-25; Gellhorn, Public Participation in Administrative Proceedings, 81 YALE L.J. 359, 361 (1972).

24. See Bazelon, supra note 10 , at 829 ; Gellhorn, supra note 23 , at 361 ; Stewart, supra note 5, at $1670,1712$.

25. Bonfield, Representation for the Poor in Federal Rulemaking, 67 MICH. L. REV. 511, 511-12 (1969); Stewart, supra note 5, at 1686-87, 1713.

26. See sources cited supra note 21 .

27. The term "internal management standards" may cover a lot of ground. For example, it would not be improper to view structural injunctions that have been used in the school and prison contexts as court-imposed internal management standards. It is therefore important to note that the proposed reforms constitute a relatively low level of intrusion into agency management. Rather than completely restructuring an agency's mode of operation, they merely force the agency to be more open and responsive to participation and scrutiny by outsiders. See pp. 744-52 infra. In contrast, see, for example, Pugh v. Locke, 406 F. Supp. 318 (M.D. Ala. 1976), affd sub nom. Newman v. Alabama, 559 F.2d 283 (5th Cir. 1977), cert. denied, 438 U.S. 915 (1978) (holding that conditions of certain prisons violated prisoners' Eighth Amendment rights and giving detailed instructions to state concerning how situation was to be rectified); Newman v. Alabama, 349 F. Supp. 278 (M.D. Ala. 1972), aff'd in part, 503 F.2d 1320 (5th Cir. 1974), cert. denied, 421 U.S. 948 (1975) (holding same and again giving 
branch" ${ }^{32}$ while allowing the broad delegation of authority that is necessary to regulate in areas of factual or normative complexity or uncertainty. Each branch of government has recently recognized the value of imposing internal management standards and has acted or is seriously considering acting to impose such standards upon agencies. Despite remarkable similarity among the actions or proposals of each branch, no attempt has been made to coordinate their efforts.

\section{A. The Judicial Response}

Over the past three decades, courts have struggled to remain within their sphere of competence and legitimacy, and yet to check and legitimate the discretion of administrative agencies in promulgating policy. ${ }^{29}$ The issue of judicial competence arises because judges often do not have the training necessary to resolve difficult factual questions or evaluate the legitimacy of inferences from the facts..$^{30}$ Furthermore, courts are thought to lack the democratic legitimacy to supply norms that are missing from an agency statute. ${ }^{31}$

In the last fifteen years, uneasiness over the increased pervasiveness of government has led courts and commentators to reexamine the previously accepted notion that judicial review of agency determinations ought to be highly deferential. ${ }^{32}$ While some decisions of the early 1970 's retained the

detailed instructions concerning how to correct the situation); Wyatt v. Stickney, 325 F. Supp. 781 (M.D. Ala. 1971), enforced, 344 F. Supp. 373 (M.D. Ala. 1972) and 344 F. Supp. 387 (M.D. Ala. 1972), modified sub nom. Wyatt v. Aderholt, 503 F.2d 1305 (5th Cir. 1974) (holding that treatment of patients involuntarily confined in mental hospital violated patients' constitutional rights and defining, with great specificity, minimum standards).

28. Charges that agencies are a "headless fourth branch" of the government can be found at least as far back as 1937. See PRESIDENT'S COMMITTEE ON ADMINISTRATIVE MANAGEMENT, REPORT WITH SPECIAL STUDIES 39-40 (1937).

29. See, e.g., American Pub. Gas Ass'n v. Federal Power Comm'n, 567 F.2d 1016, 1063-64 (D.C. Cir. 1977), cert. denied, 435 U.S. 907 (1978) (discussing standard of judicial review of rates set by Federal Power Commission); Stewart, supra note 5, at 1679-81.

30. See International Harvester Co. v. Ruckelshaus, 478 F.2d 615, 651 (D.C. Cir. 1973) (Bazelon, C.J., concurring); Bazelon, supra note 10, at 817; Bazelon, Risk and Responsibility, 205 SCIENCE 277, 278 (1979); Wright, The Courts and the Rulemaking Process: The Limits of Judicial Review, 59 CORnell L. REv. 375, 393 (1974). But see Greater Boston Television Corp. v. FCC, 444 F.2d 841, 850 (D.C. Cir. 1970), cert. denied, 403 U.S. 923 (1971) (Leventhal, J.) ("A court does not depart from its proper function when it undertakes a study of the record, hopefully perceptive, even as to the evidence on technical and specialized matters . . ..") See generally McGarity, Substantive and Procedural Discretion in Administrative Resolution of Science Policy Questions: Regulating Carcinogens in EPA and OSHA, 67 GEO. L.J. 729 (1979).

31. See, e.g., Industrial Union Dep't, AFL-GIO v. Hodgson, 499 F.2d 467, 475 (D.C. Cir. 1974) (refusing to overturn basic policy determinations underlying OSHA asbestos dust standard, but remanding standard for clarification of reasons for certain determinations); Bazelon, supra note 10, at 822; Stewart, supra note 5 , at 1786-87.

32. DeLong, Informal Rulemaking and the Integration of Law and Policy, 65 VA. L. REV. 257, 261 (1979); see Wright, supra note 14, at 579. The criticisms of government came from the entire political spectrum. See Wright, supra note 14, at 579. 
highly deferential standard of review, ${ }^{33}$ other courts have constrained agency discretion by reading vague statutory authority narrowly. ${ }^{34}$ Some judges and commentators have urged the elimination of broad discretion through revival of the non-delegation doctrine. ${ }^{35}$ Other courts and commentators seem to believe that vigorous substantive review that immerses the court in all data presented to it is the solution to agency discretion. ${ }^{36}$ By contrast, over the past decade many courts, led by the Court of Appeals for the District of Columbia, have chosen a weak form of structural review of the agency's rulemaking process as the primary means of checking agency discretion. ${ }^{37}$

This form of review is designed to constrain agency discretion while recognizing the limits of judicial competence and legitimacy. ${ }^{38}$ It focuses on the rule-making process and defers to agency determinations of fact and law when either or both are unclear. ${ }^{39}$ Instead of a strict substantive

33. See, e.g., Camp v. Pitts, 411 U.S. 138 (1973) (per curiam) (upholding denial of bank charter despite minimal and conclusory explanation of rule); United States v. Allegheny-Ludlum Steel Corp., 406 U.S. 742, 748-49 (1972) (employing, in upholding rule promulgated by ICC, highly deferential standard of review stated in Assigned Car Cases, 274 U.S. 564 (1927)); Angel v. Butz, 487 F.2d 260, 262-63 (10th Cir. 1973) (allowing Secretary of Agriculture to rely upon "expertise" and material outside of the record in determining fair and reasonable wages for sugar workers).

34. See, e.g., Industrial Union Dep't, AFL-GIO v. American Petroleum Inst., 448 U.S. 607, 63946 (1980) (plurality opinion reading unclear Occupational Safety and Health statute to require finding of "significant" benefits from a standard issued pursuant thereto, prior to its issuance).

35. See supra note 14.

36. See, e.g., Texas v. EPA, 499 F.2d 289 (5th Cir. 1974), cert. denied, 427 U.S. 905 (1976) (basing decision upholding EPA disapproval of state implementation plan on detailed independent review of entire record); Portland Cement Ass'n v. Ruckelshaus, 486 F.2d 375 (D.C. Cir. 1973), cert. denied, 417 U.S. 921 (1974) (remanding stationary source standard for procedural reasons but only after extensive examination of correctness of various substantive determinations made by EPA).

37. See DeLong, supra note 32, at 259, 262; McGowan, supra note 12, at 1167; Rodgers, $A$ Hard Look At Vermont Yankee: Environmental Law Under Close Scrutiny, 67 GEO. L.J. 699, 704-08 (1975); Verkuil, Judicial Review of Informal Rulemaking, 60 VA. L. REV. 185, 207-08 (1974). Though internal management review has developed primarily in the last fifteen years, its doctrinal origins can be traced further back. See SEC v. Chenery Corp., 318 U.S. 80 (1943).

38. Indeed, the legitimacy and competence problems suggest that the only effective and legitimate tool that the courts have left is review of agency internal management. See DeLong, supra note 32, at 282-309.

39. See, e.g., American Pub. Gas Ass'n v. Federal Power Comm'n, 567 F.2d 1016, 1063 (D.C. Cir. 1977), cert. denied, 435 U.S. 907 (1978) (upholding Federal Power Commission gas rate order on basis that commission had employed "reasoned decisionmaking and fair procedure" and had responded to objections in promulgating orders); Environmental Defense Fund v. EPA, 548 F.2d 998 (D.C. Cir. 1976), cert. denied, 431 U.S. 925 (1977) (upholding various substantive determinations of EPA concerning suspension of registrations of several pesticides but striking down exemption of existing stocks of pesticides for failure to inquire into amount of such stocks left and problem of returning and disposing of them); Ethyl Corp. v. EPA, 541 F.2d 1 (D.C. Cir.), cert. denied, 426 U.S. 941 (1976) (en banc) (upholding EPA order requiring reductions in lead content of gasoline); Industrial Union Dep't., AFL-CIO v. Hodgson, 499 F.2d 467 (D.C. Cir. 1974) (holding that great deference should be accorded determinations when information is lacking or unclear, but remanding for failure to explain certain determinations); Committee for Nuclear Responsibility, Inc. v. Seaborg, 463 F.2d 783, 787 (D.C. Cir. 1971) (per curiam) (dictum) (in reviewing environmental impact statements, court is not to rule on relative merits of competing scientific opinions but only to ensure that statement sets forth opposing scientific views). 


\section{Informal Rulemaking}

review, it seeks to ensure that the agency's rule-making process is "openly informed, reasoned, and candid." 40

In an effort to ensure opportunities for meaningful public participation, the courts that have adopted this form of review have required timely notice that discloses the bases of a proposed rule. ${ }^{41}$ Demanding that the agency take a "hard look" at all the relevant factors, ${ }^{42}$ these courts have required coherent written demonstration ${ }^{43}$ that serious issues raised by participants in the rulemaking process were considered and evaluated.4 Indeed, in some instances courts have required discussion of issues that were not raised by participants. ${ }^{45}$ Though internal management review is deferential toward agency factual and policy determinations, it demands that the agency explain such determinations. ${ }^{46}$ Furthermore, it sometimes

40. Wright, supra note 30 , at 379 ; see DeLong, supra note 32, at 265-72; Rogers, supra note 37 , at 704-07.

41. See, e.g., Aqua Slide 'N' Dive Corp. v. CPSC, 569 F.2d 831, 842 (5th Cir. 1978) (setting aside safety standard for swimming pools for failure to give meaningful opportunity for public comment); United States v. Nova Scotia Food Prods. Corp., 568 F.2d 240 (2d Cir. 1977) (holding FDA's failure to disclose scientific basis for proposed regulation concerning smoked whitefish was reversible error); Portland Cement Ass'n v. Ruckelshaus, 486 F.2d 375 (D.G. Cir. 1973), cert. denied, 417 U.S. 921 (1974) (remanding stationary source standard for cement plants for reasons including failure of EPA to disclose test results that were basis for proposed regulation).

42. See, e.g., Gitizens to Preserve Overton Park v. Volpe, 401 U.S. 402, 415 (1971) (reversing lower courts' holdings allowing Secretary of Department of Transportation to authorize use of federal funds to construct highway through a public park and remanding to lower court for in-depth scrutiny of Secretary's decision); Asarco v. EPA, 616 F.2d 1153, 1161-62 (9th Cir. 1980) (vacating EPA order requiring installation of a sampling station in smokestack at copper smelter, because of inadequate consideration of relevant factors); Portland Cement Ass'n v. Ruckelshaus, 486 F.2d 375, 394-95 (D.C. Cir. 1973), cert. denied, 417 U.S. 921 (1974) (remanding stationary source standard for reasons including inadequate consideration of relevant factors).

43. See, e.g., Aqua Slide 'N' Dive Corp. v. CPSC, 569 F.2d 831, 837-38 (5th Gir. 1978) (dictum) (holding that substantial evidence did not support safety standard of swimming pool slides); Texas v. EPA, 499 F.2d 289, 297 (5th Cir. 1974), cert. denied, 427 U.S. 905 (1976) (dictum) (in part upholding legality of EPA determination that Texas' air quality implementation plan was inadequate); see also Wright, New Judicial Requisites for Informal Rulemaking: Implications for the Environmental Impact Statement Process, 29 AD. L. REV. 59 (1977) (suggesting that courts should and will summarily vacate agency action when record kept by agency is confused or otherwise inadequate).

44. E.g., Bunker Hill Co. v. EPA, 572 F.2d 1286, 1299-1301 (9th Cir. 1977) (remanding rejection of state implementation plan, in part due to failure to respond to criticism of key factual assumption); American Iron \& Steel Inst. v. EPA, 568 F.2d 284, 299 (3d Cir. 1977) (holding that EPA must respond to contention that age of steel plant affects plants' pollution control costs); Portland Cement Ass'n v. Ruckelshaus, 486 F.2d 375, 392-93 (D.C. Cir. 1973), cert. denied, 417 U.S. 921 (1974) (remanding stationary source standard for reasons including failure to respond to challenge to accuracy of test data relied upon).

45. See, e.g., Calvert Cliff' Coordinating Comm'n. v. AEC, 449 F.2d 1109, 1119 (D.C. Cir. 1971) (holding that AEC must consider environmental values not raised by parties or staff); Scenic Hudson Preservation Conference v. FPC, 354 F.2d 608, 620 (2d Cir. 1965), cert. denied, 384 U.S. 941 (1966) (remanding FPC order granting license to construct hydroelectric project, in part due to FPC failure to inquire beyond record). But see Vermont Yankee Nuclear Power Corp. v. Natural Resources Defense Council, 435 U.S. 519, 551-54 (1978) (suggesting that agency need not ferret out alternatives unless a party makes a showing that is "sufficient to require reasonable minds to inquire further").

46. American Iron \& Steel Inst. v. EPA, 568 F.2d 284, 310 (3d Cir. 1977) (requiring EPA to explain and support determination that certain cooling devices would not cause evaporation of water); Synthetic Organic Chem. Mfrs. Ass'n v. Brennan, 503 F.2d 1155, 1160 (3d Gir.) (dictum), cert. 
requires that the agency explain any inconsistency with previous determinations. ${ }^{47}$

Courts have developed these internal management standards on a caseby-case basis. Though many courts seem to agree that internal management requirements must be imposed, there is little agreement on which requirements should be imposed and under what circumstances. ${ }^{48}$

\section{B. The Executive Branch Response}

Executive branch attempts to constrain agency discretion began with President Ford's Executive Order $11,821,{ }^{49}$ requiring executive branch agencies to prepare an "inflation impact statement" (IIS) s0 $^{\circ}$ for each "major" ${ }^{\prime \prime}$ federal action. Each IIS was to contain a written analysis of the

denied, 420 U.S. 973 (1974); Dry Color Mfrs. Ass'n v. Department of Labor, 486 F.2d 98, 106-07 (3d Cir. 1973) (vacating emergency standards for suspected carcinogens for failure to explain basis for suspicion and choice of standard); Citizens Ass'n of Georgetown v. Zoning Comm'n, 477 F.2d 402 (D.C. Cir. 1973) (requiring zoning commission to explain failure to "downzone" waterfront area).

47. See American Meat Inst. v. EPA., 526 F.2d 442, 459-60 (7th Cir. 1975) (striking down EPA TSS limitation for complex slaughterhouses because of EPA failure to explain deviation from normal practice of relying upon questionnaire data).

48. $1 \mathrm{~K}$. DAVIS, ADMINISTRATIVE LAW TREATISE § 6:1, at 450 (1978); DeLong, supra note 32, at 283, 290-307; Verkuil, The Emenging Concept of Administrative Procedure, 78 ColuM. L. REV. 258, 288-89 (1978); Verkuil, supra note 37, at 244.

Judicial opinions concerning the issue of the importance of giving notice are an example of the disagreement that exists concerning the when and what of imposing internal management requirements. Compare Yassini v. Crosland, 618 F.2d 1356, 1360 (9th Cir. 1980) (per curiam) (exempting Immigration and Naturalization Service from notice requirement of Administrative Procedure Act despite absence of required express finding of "good cause") and United States Steel Corp. v. EPA, 605 F.2d 283 (7th Cir. 1979), cert. denied, 444 U.S. 1035 (1980) (exempting EPA from notice and good cause requirements in designating areas that do not meet air quality standards) with Sharon Steel Corp. v. EPA, 597 F.2d 377 (3d Cir. 1979) (finding no good cause for EPA failure to give notice concerning rule designating areas not in compliance with ambient air quality standards, and remanding rule) and United States Steel Corp. v. EPA, 595 F.2d 207 (5th Cir. 1979) (same). Even assuming notice must be given, a disagreement exists concerning whether or not an agency that relied on empirical data in determining that a rule might be necessary must disclose that methodology in its notice of proposed rulemaking. Compare Ethyl Corp. v. EPA, 541 F.2d 1, 82-94 (D.C. Cir.), cert. denied, 426 U.S. 941 (1976) (en banc) (upholding EPA order requiring reductions in lead content in gasoline despite failure to disclose scientific studies relied upon) with cases cited supra note 41 .

49. 3 C.F.R. 203 (1975), reprinted in 12 U.S.C. $\$ 1904$ (1976) (expiration date extended and name changed by Exec. Order No. 11,949, 3 C.F.R. 161 (1977)) [hereinafter reference to U.S.C. will be omitted].

50. It was later realized that the term "inflation impact statement" reflects poorly the nature of the required analysis; when the Order was extended in 1976, the analysis was called an "economic impact statement." Exec. Order No. 11,949, 3 C.F.R. 161 (1977).

51. Originally agencies were left to develop their own criteria for determining what was a "major" proposal, though the criteria developed had to be submitted to OMB for approval. Office of Management and Budget, Gircular No. A-107 (Jan. 28, 1975). Eventually the Council on Wage and Price Stability adopted a list of suggested criteria, which essentially defined "major" as entailing a cost of $\$ 100$ million or more in one year, or $\$ 150$ million or more in two years. See STAFF OF THE COUNCIL ON WAGE AND PRICE STABILITY \& THE OFFICE OF MANAGEMENT AND BUDGET, AN EVALUATION OF THE INFLATION IMPACT STATEMENT PROGRAM PREPARED FOR THE ECONOAIC POLICY BOARD 15 (1976); Note, The Inflation Impact Statement Program: An Assessment of the First Two Years, 26 AM. U.L. REV. 1138, 1150 n.79 (1977). The criteria were adopted in large part by all covered agencies. $I d$. 
expected costs and benefits of proposed federal action and a review of the alternatives that were considered..$^{52}$ Though increased public participation in the regulatory process was also considered an essential element of the program, the only step taken to increase participation was to require publication of the IIS. ${ }^{53}$

President Carter's Executive Order 12,044 implemented an internal management program that was both broader and more detailed than the IIS program. ${ }^{54}$ It required agencies to prepare a draft "regulatory analysis" before issuing public notice of proposed "major"ss rules, and to publish a final regulatory analysis concurrent with the issuance of such rules. ${ }^{56}$ Both analyses were required to give "a succinct statement of the problem; a description of the major alternative ways of dealing with the problem that were considered by the agency; an analysis of the economic consequences of each of these alternatives and a detailed explanation of the reasons for choosing one alternative over the others." ${ }^{257}$ In addition, Executive Order 12,044 sought to increase opportunities for meaningful public participation and scrutiny by requiring agencies to consider a variety of methods for giving more effective notice of proposed regulations, ${ }^{58}$ by increasing the time for public comment to sixty days where possible, ${ }^{59}$ and by making both the draft and final regulatory analyses easily available to the public. ${ }^{60}$

President Reagan's Executive Order 12,291, ${ }^{61}$ though superseding Ex-

52. See Office of Management and Budget, Circular No. A-107 § 4(b) (Jan. 28, 1975) (implementing Exec. Order No. 11,821).

53. See Note, supra note 51 , at 1163.

54. 3 C.F.R. 152 (1979), reprinted in 5 U.S.C. $§ 553$ (Supp. III 1979) [hereinafter reference to U.S.C. will be omitted].

55. The definition of a major rule was similar to the definition under Ford's Executive Order:

[R] legulatory analyses [must be] performed for all regulations which will result in (a) an annual effect on the economy of $\$ 100$ million or more; or (b) a major increase in costs or prices for individual industries, levels of government or geographic regions.

Exec. Order No. 12,044 § 3(a)(1), 3 C.F.R. 152, 154 (1979).

56. Id. § 3(b)(2)-(3), 3 C.F.R. at 155.

57. Id. $\S 3(\mathrm{~b})(1), 3$ C.F.R. at 154 .

58. Agencies were required to publish "at least semi-annually an agenda of significant regulations under development and review . . . [describing, at a minimum] the regulations being considered by the agency, the need for and the legal basis for the action being taken, and the status of regulations previously listed on the agenda." Id. $§ 2$ (a), 3 C.F.R. at 153. In addition, agencies were to "consider" a variety of ways to "give the public an early and meaningful opportunity to participate in the development of agency regulations . . . including (1) publishing an advance notice of proposed rulemaking; (2) holding open conferences or public hearings; (3) sending notices of proposed regulations to publications likely to be read by those affected; and (4) notifying interested parties directly." Id. § 2(c), 3 C.F.R. at 153 .

59. A brief explanation was required of any determination by the agency that the 60 day period was not possible. Id. $\S 2$ (c), 3 C.F.R. at 153 . The Executive Order suggests that the number of instances in which the sixty day period is not possible ought to be "few." Id.

60. Id. $\S 3(\mathrm{~b})(2)-(3), 3$ C.F.R. at 155.

61. Exec. Order No. 12,291, 46 Fed. Reg. 13,193 (1981), reprinted in 5 U.S.C.A. § 601 (West Supp. 1982) [hereinafter reference to U.S.C.A. will be omitted]. 
ecutive Order $12,044,{ }^{62}$ retains many of its essential features. It requires agencies to peform, for "major" ${ }^{33}$ rules, preliminary and final "Regulatory Impact Analyses" (RIAs) that contain descriptions of the potential costs and benefits of a rule, including its nonquantifiable effects, and a determination of the rule's potential net benefits. ${ }^{64}$ RIAs must also describe any alternative approaches that could be more cost effective than the approach chosen, and explain the legal reasons for rejection of the most cost-effective approach. ${ }^{65}$ Like its predecessors, President Reagan's Order seeks to assure meaningful public participation in the regulatory process. In addition to making the RIAs available to the public, ${ }^{66}$ it requires the agency to include with its notice of proposed rulemaking "a brief statement setting forth the agency's initial determination whether the proposed rule is a major rule, together with the reasons underlying that determination,"67 and a "brief summary of the agency's preliminary Regulatory Impact Analysis." ${ }^{168}$ The agency is further ordered to pay "full attention to public comments in general and the comments of persons directly affected by the rule in particular"69 in assessing the validity of the factual conclusions upon which the rule is based.

Thus, not only the judiciary but each of the last three Presidents has imposed constraints on the rulemaking process to ensure that it is "openly informed, reasoned and candid." 70 The Executive Orders may not, however, be motivated solely by the desire to improve the efficacy and legitimacy of agency action. ${ }^{71}$ In addition, the Executive may view them as means to further its own policy goals by increasing the accountability to

62. Id. $\S 10,46$ Fed. Reg. at 13,198.

63. The term "major" is defined similarly to the definition in Executive Order 12,044:

"Major rule" means any regulation that is likely to result in:

(1) An annual effect on the economy of $\$ 100$ million or more;

(2) A major increase in costs or prices for consumers, individual industries, Federal, State, or local government agencies, or geographic regions; or

(3) Significant adverse effects on competition, employment, investment, productivity, innovation, or on the ability of United States-based enterprises to compete with foreign-based enterprises in domestic or export markets.

Id. § 1(b), 46 Fed. Reg. at 13,193-94.

64. Id. § 3(d), 46 Fed. Reg. at 13,194.

65. Id.

66. Id. § 3(h), 46 Fed. Reg. at 13,195.

67. Id. $\S 3(\mathrm{~g})(1), 46$ Fed. Reg. at 13,195 .

68. Id. $\S 3(\mathrm{~g})(2), 46$ Fed. Reg. at 13,195 .

69. Id. $\S 4(\mathrm{~b}), 46$ Fed. Reg. at 13,195 .

70. See supra note 40 .

71. Improving the administrative rulemaking process through internal management standards is, however, one motive behind the executive actions. See, e.g., R. REAGAN, AMERICA's NEW BEGINNING: A PROGRAM FOR ECONOMIC RECOVERY (1981), excerpts of which are reprinted in EXECUTIVE OFFICE OF THE PRESIDENT, MATERIALS ON PRESIDENT REAGAN'S PROGRAM OF REGULATORY RELIEF 55-57 [hereinafter cited as MATERIALS]. See generally Neudstadt, The Administration's Regulatory Reform Program: An Overview, 32 AD. L. REV. 129, 137-145 (1979) (discussing President Carter's program). 
its offices of administrative agencies. ${ }^{72}$

\section{The Congressional Response}

During the 96th Congress eight bills were introduced that basically reiterated the requirements of Executive Order 12,044 and extended it to agencies outside the executive branch. ${ }^{73}$ Two of the bills received substantial attention. ${ }^{74}$ During the 97 th Congress eight similar bills ${ }^{75}$ have been

72. President Reagan's Executive Order enhances the ability of the President to control agency policy through selective enforcement of the requirements, going beyond its predecessors in two significant respects. First, it gives OMB vast oversight authority. See infra pp. 754-55. Second, it creates a substantive requirement that, to the extent permitted by law, agencies not undertake any regulatory action unless the action's benefits exceed its costs by more than any alternative approach:

In promulgating new regulations, reviewing existing regulations, and developing legislative proposals concerning regulation, all agencies, to the extent permitted by law, shall adhere to the following requirements:

(a) Administrative decisions shall be based on adequate information concerning the need for and consequences of proposed government actions;

(b) Regulatory action shall not be undertaken unless the potential benefits to society from the regulation outweigh the potential costs to society;

(c) Regulatory objectives shall be chosen to maximize the net benefits to society;

(d) Among alternative approaches to any given regulatory objective, the alternative involving the least net cost to society shall be chosen; and

(e) Agencies shall set regulatory priorities with the aim of maximizing the aggregate net benefits to society, taking into account the condition of the particular industries affected by regulations, the condition of the national economy, and other regulatory actions contemplated for the future.

Id. $\S 2$.

This substantive prescription raises serious questions of constitutionality and legality. See M. ROSENBERG, PRESIDENTIAL CONTROL OF AGENCY RULEMAKING: AN ANALYSIS OF CONSTITUTIONAL ISSUES THAT MAY BE RAISED BY EXECUTIVE ORDER 12291 (1981); infra p. 755.

73. S. 262, 96th Cong., 1st Sess., 125 CONG. REC. S861 (1979); H.R. 3263, 96th Cong., 1st Sess. (1979); S. 1291, 96th Cong., 1st Sess., 125 CONG. REC. S7128 (1979); H.R. 75, 96th Cong., 1st Sess. (1979); S. 93, 96th Cong., 1st Sess., 125 CONG. REC. S287 (1979); H.R. 4233, 96th Cong., 1st Sess. (1979) (identical to S. 262); S. 755, 96th Cong., 1st Sess., 125 CoNG. REC. S3339 (1979) (identical to H.R. 3263); S. 2147, 96th Cong., 1st Sess., 125 CONG. REC. S19,040 (1979).

74. H.R. 3263, 96th Cong., 1st Sess. (1979) went through hearings, see Regulation Reform Act of 1979: Hearings on H.R. 3263 Before the Subcomm. on Administrative Law and Governmental Relations of the House Comm. on the Judiciary, 96th Cong., 1st Sess. (1979), was forwarded to the full committee, marked up, and on September 25, 1980, was placed on the Union Calendar. Hereinafter all references to H.R. 3263 will be to the bill's final version, reprinted in H. R. REP. No. 1393, 96th Cong., 2d Sess. 39 (1980). The Senate Governmental Affairs Committee held hearings on S. 755, 96th Cong., 1st Sess., 125 CONG. REC. S3339 (1979), which was identical to H.R. 3263, on S. 262, 96th Cong., 1st Sess., 125 CONG. REC. S861 (1979), and on other regulatory reform legislation, see Hearings Before the Senate Comm. on Government Affairs on S. 262, S. 755, S. 445, S. 93 and Other Regulatory Reform Legislation, 96th Cong., 1st Sess. (1979) [hereinafter cited as Senate Hearings]. The Governmental Affairs Committee referred both S. 755 and S. 262 to the Senate Judiciary Committee, which held hearings on them jointly with its Administrative Practice Subcommittee. See ReguJatory Reform: Hearings Before the Committee on the Judiciary, 96th Cong., 1st Sess. (1979). S 262 was reported to the Senate and assigned number 850 on the Senate Legislative Calendar on May 29, 1980. Hereinafter all references to S. 262 will be to the version reprinted in Senate Hearings, supra, pt. 2 , at 668 .

75. See H.R. 1, 97th Cong., 1st Sess. (1981); H.R. 300, 97th Cong., 1st Sess. (1981); H.R. 700, 97th Cong., 1st Sess. (1981); H.R. 746, 97th Cong., 1st Sess. (1981); H.R. 3339, 97th Cong., 1st Sess. (1981); S. 401, 97th Cong., 1st Sess. (1981); S. 405, 97th Cong., 1st Sess. (1981); S. 1080, 97th Cong., 1st Sess., 127 CONG. REC. S4231 (1981). 
introduced, and rapid action has been taken on two of them. ${ }^{76}$ This Note will concentrate its discussion on four bills, the two in each Congress that have received the most attention.

The constraints placed on agencies by all four bills are similar both to each other and to the Executive Orders. The bills require agencies to issue a preliminary regulatory analysis ${ }^{77}$ concurrent with notice of a proposed major rule. ${ }^{78}$ The essential elements of this preliminary regulatory analy-

76. S. 1080, 97th Cong., 1st Sess., 127 CONG. REC. S4231 (1981), was introduced on April 30, 1981, by Senator Laxalt and his co-sponsors, and was referred jointly to the Committees on the Judiciary and Governmental Affairs. The Judiciary Committee held hearings, amended the bill and unanimously reported out an amended copy on July 17, 1981. On September 18, 1981, the Governmental Affairs Committee reported out an amended copy of the bill that differed from the Judiciary Committee's version. On November 30, 1981, Senators Laxalt, Leahy, Roth, and Eagleton proposed a "consensus substitute for S. 1080," which was subsequently placed on the Senate Calendar for a vote. The consensus substitute passed the Senate with only minor relevant changes by a 94-0 vote on March 24, 1982. See 128 Cong. Rec. S 2693-2722. Hereinafter all references to S. 1080 will be to the "consensus substitute," amendment number 640 , Number 274 on the Senate Calendar.

H.R. 746, 97th Cong., 1st Sess. (1981), was introduced by Mr. Danielson on January 6, 1981, and referred to the House Committee on the Judiciary, which requested comments from various federal agencies, and referred the bill to its Subcommittee on Administrative Law and Governmental Relations. The Subcommittee held hearings between April 2, 1981, and May 19, 1981, and held mark-up sessions in July, 1981. Hereinafter all references to H.R. 746 will be to the amended version dated July $30,1981$.

77. The term "preliminary regulatory analysis" is used by two of the four bills. Sce S. 1080 , supra note 76, § 4(a) (proposed § 622(c)); H.R. 3263, supra note 74, § 101(a) (proposed § 602(b)). S. 262 , supra note $74, \S 102$ (proposed $\S 602$ ), refers to similar requirements as an "initial regulatory analysis," while H.R. 746, supra note $76, \$ 101$ (b) (proposed $\$ 622$ ) simply calls the requirements "[a]dditional procedures for major rules." Hereinafter all such requirements will be referred to as "preliminary regulatory analysis" requirements.

78. All four bills define "major rule" similarly, though they differ somewhat in which costs they emphasize. S. 1080 states:

The term "major rule" means-

(A) a rule or a group of closely related rules that . . . is likely to have an annual effect on the economy of $\$ 100,000,000$ or more in reasonably quantifiable direct or indirect enforcement and compliance costs; and

(B) a rule or a group of closely related rules that is . . . likely to result in -

(i) a substantial increase in costs or prices for wage earners, consumers, individual industries, nonprofit organizations, Federal, State or local government agencies, or geographic regions; or

(ii) significant adverse effects on competition, employment, investment, productivity, innovation, the environment, public health or safety, or the ability of enterprises whose principal places of business are in the United States to compete in domestic or export markets.

S. 1080 , supra note $76, \S 4(a)$ (proposed $\S 621(4)$ ). The definition of a major rule in H.R. 746 is the same, except that it does not contain a provision akin to $B$ (ii) and does not refer to the effect of the rule on domestic businesses. See H.R. 746, supra note 76, § 101(b) (proposed § 621(3)). S. 262 defines a major rule as a rule that is "likely to result in an effect on the economy in any one year of $\$ 100,000,000$ or more . . . or is likely to have an equally significant effect." S. 262 , supra note $74, \$$ 102 (proposed $\S 601(3)$ ). H.R. 3263 begins with S. 262's definition and includes, as well, rules that will "cause a substantial change in costs or prices for individual industries, geographic regions, or levels of government." H.R. 3263, supra note 74, § 101(a) (proposed § 601(3)). It urges in addition that special attention be paid to the impact on "small business and small organizations." Id.

An important issue related to the definition of "major rule" is who decides whether a rule falls within the definition. The bills of the 96th Congress, following the example of Executive Order 12,044 , leave the decision to the agency. The bills of the 97 th Congress, following the example of Executive Order 12,291, allow the President, or a designee of his choice within the Executive Office of the President, to reverse an agency determination that a rule is not major. See S. 1080, supra note 76, 
$\operatorname{sis}^{79}$ are: a statement of the need for and objectives of the rule; ${ }^{80}$ a description of alternatives to the rule, including the least costly alternative; $;^{81}$ an assessment of the effects of the rule on the country as a whole and on particular subgroups; ${ }^{82}$ and a description of agency methodology for resolving factual disputes. ${ }^{83}$ The bills also attempt to improve participation by making the preliminary regulatory analysis available to the public, ${ }^{84}$ by mandating the creation of a regulatory agenda and calendar, ${ }^{85}$ and by increasing the opportunity for public comment. ${ }^{86}$ Like the Executive Orders that they would supersede, the bills require the agency to issue a final regulatory analysis when it issues a major rule. The requirements of the final regulatory analysis parallel those of the preliminary regulatory analysis. ${ }^{87}$

§4(a) (proposed § 621(4)); H.R. 746, supra note 76, at § 101(a) (proposed § 621(3)(c)).

79. Several bills contain requirements of the preliminary and final regulatory analyses in addition to the requirements mentioned in the text. Three bills require discussion of the relative advantages and disadvantages of performance standards as opposed to design standards. H.R. 746, supra note 76, $\S 101$ (b) (proposed $\S 622(\mathrm{~b})(5)$ ); H.R. 3263, supra note 74, § 101(a) (proposed $\S 602(\mathrm{~b})(6)$ ); S. 1080, supra note 76, $\S 4(\mathrm{a})$ (proposed $\S 622(\mathrm{c})(2)(\mathrm{C})(\mathrm{iii})$ ). S. 1080 also requires the agency to find that the benefits "justify" the costs, unless the agency's enabling statute directs otherwise. Id. $\S 4$ (a) (proposed $\S 622$ (d)(2)(B)). H.R. 3263 requires the agency to estimate "the effect of the proposed rule on small businesses, small organizations, small governmental jurisdictions, and competition in interstate and foreign commerce." H.R. 3263, supra note 74, $\$ 101$ (a) (proposed $\S 602(\mathrm{~b})(5)$ ).

80. H.R. 746, supra note 76, $\S 101$ (b) (proposed $\S 622$ (b)(1)), S. 1080, supra note $76, \S 3$ (proposed $\S 553(\mathrm{~b})(1)(\mathrm{B})$ ); H.R. 3263, supra note 74, $\S 101$ (a) (proposed $\S 602(\mathrm{~b})(1)$ ); S. 262, supra note 74 , at $\S 102$ (proposed $\S 602(\mathrm{~b})(1),(2))$.

81. H.R. 746, supra note 76, §101(b) (proposed $\$ 622(\mathrm{~b})(2)$ ). See S. 1080, supra note 76, § 4(a) (proposed $\S 622(\mathrm{c})(2)(\mathrm{C})$ ); S. 262, supra note 74, $\S 102$ (proposed $\S 602(\mathrm{~b})(3)$ ), (4)); H.R. 3263, supra note 74, § 101(a) (proposed $\S 602(\mathrm{~b})(2)$ and (4)).

82. S. 1080 , supra note $76, \S 4$ (a) (proposed $\S 622$ (c)(2)(A)-(B)); H.R. 746, supra note $76, \S$ 101(b) (proposed $\S 622$ (b)(3)); H.R. 3263, supra note 74, $\S 101$ (a) (proposed $\S 602(\mathrm{~b})(3),(5))$. CI. S. 262 , supra note $74, \S 102$ (proposed $\S 602(\mathrm{~b})$ ) (not mentioning any specific subgroups).

83. H.R. 746, supra note $76, \S 101$ (b) (proposed $\S 622(b)(6)$ ). Cf. S. 1080 , supra note $76, \S \S 3$, 4(a) (proposed $\S \S 553(\mathrm{~b})(1)(\mathrm{F}), 622(\mathrm{c})(2)(\mathrm{D})$ ) (including, as well, requirement that agencies specify ranges of predictions and explain margins of errors for quantification method when relevant). H.R. 3263 and S. 262 contain no provision similar to this one.

84. S. 1080 , supra note $76, \S 3$ (proposed $\S 553(\mathrm{I})(1)(E)$ ); H.R. 746 , supra note $76, \S 101$ (b) (proposed $\S 622(\mathrm{e})(2)$ ); H (proposed $\S 602(\mathrm{e})(2)$ ); see also S. 262, supra note $74, \S 102$ (proposed $\S$ 602(c)) (requiring publication of the preliminary regulatory analysis in Federal Register and requiring agency to take additional unspecified steps to "ensure that interested members of the public receive notice of the initial regulatory analysis").

85. S. 1080, supra note 76, $\S 4$ (a) (proposed $\S 632$ ); H.R. 746, supra note 76, $\S 101$ (b) (proposed $\S \S 631-632$ ); S. 262 , supra note $74, \S 102$ (proposed $\S 622$ ); H.R. 3263, supra note $74, \S 101$ (a) (proposed $\S \S 621-622)$.

86. The bills demand that interested persons be given at least sixty days to comment on the proposed rulemaking. See S. 1080 , supra note $76, \S 3$ (proposed $\S 553($ c)(1)); H.R. 746, supra note $76, \S$ 101(b) (proposed $\S 622(\mathrm{~g})$ ); S. 262, supra note 74, $\S 102$ (proposed $\S 602(\mathrm{c})$ ); H.R. 3263, supra note $74, \S 101$ (a) (proposed $\S 602$ (c)). H.R. 3263 also provides for twenty days to comment on the public comments received during the sixty day period. Id. S. 1080 also requires that the agency provide an opportunity for oral presentation of views and cross-examination of agency employees. S. 1080, supra note $76, \S 3$ (proposed $\S 553(\mathrm{c})(3)(\mathrm{A}))$.

87. See S. 1080, supra note 76, $\S 4$ (a) (proposed $\S 622$ (d) and (e)); H.R. 746, supra note $76, \S$ 101(b) (proposed $\S 622($ c)); S. 262, supra note 74, $\$ 102$ (proposed $\S 603($ b)); H.R. 3263, supra note $74, \S 101(\mathrm{a})$ (proposed $\S 602(\mathrm{~d})$ ). 
Each branch of the federal government has sought to impose upon the agencies remarkably similar internal management requirements. The attempts are similar because each is based on three major precepts. First, they presume that agency decisionmaking will be improved by ensuring that agencies explore fully the consequences of major regulatory actions and examine alternative means of accomplishing the agency objectives. ${ }^{88}$ Second, they presume that it is desirable to force the agency to weigh costs and benefits explicitly. ${ }^{89}$ Third, they presume that it is valuable to encourage input into and public scrutiny of the weighing process. ${ }^{90}$ In short, the proposals are similar because each is a reflection of the belief that better and more legitimate agency decisionmaking will result from a process that is "openly informed, reasoned and candid."

\section{The Failure to Enforce Internal Management Standards}

Neither the executive nor the judicial attempts to impose an internal management model upon agencies have been successful. Because they fail to ensure agency compliance with their requirements, ${ }^{92}$ legislative attempts formulated during the 96th and 97th Congresses are not likely to be more successful.

\section{A. The Judiciary}

The existence of the Executive Orders and legislative proposals is testimony to the failure of the courts to impose adequate internal management standards upon the agencies. Judicial imposition of internal management standards faces two major obstacles. First, the legal basis for internal management review is unclear. ${ }^{93}$ As one commentator has noted, although at least seven different bases have been cited, none are convincing. ${ }^{94}$ Fur-

88. See H.R. REP. No. 1393, 96th Cong., 2d Sess. 39 (1980) (to accompany H.R. 3263); S. REP. No. 1013, 96th Cong., 2d Sess., pt. 1, at 29 (1980) (to accompany S. 262); Neustadt, supra note 71, at 140; cases cited supra notes 42, 44-46.

89. H.R. REP. No. 1393 , supra note 88 , at $39-40$; S. REP. NO. 1018 , supra note 88 , at 29 ; Neustadt, supra note 71 , at 140 ; cases cited supra notes $43,45,46$.

90. See Senate Hearings, supra note 74, pt. 1, at 204 (statement of Charles L. Schultze, Chairman, Council of Economic Advisors); S. REP. NO. 1018, supra note 88, at $29 ;$ H.R. REP. NO. 1393, supra note 88 , at 20 ; cases cited supra note 41 .

91. See supra note 40 .

92. Absent an enforcement mechanism, agencies are unlikely to perform tasks that they consider onerous. See Fleming v. Moberly Milk Prods. Co., 160 F.2d 259, 264-65 (D.C. Cir.), cert. dismissed, 331 U.S. 786 (1947); Wright, supra note 14, at 578, 580. It is interesting to note, however, that agency resistance to the internal management requirements may be based on a misperception of selfinterest. See infra pp. 760-62.

93. See DeLong, supra note 32, at 272-73. As Professor Black has noted in another context, "[t]he mere existence of a real and substantial doubt as to the legitimacy of a government must surely enfeeble it . . .." C. BLACK, THE PEOPLE AND THE COURT 36 (1960).

94. DeLong, supra note 32 , at 272-76. 
thermore, most opinions are very vague about their source of authority, and those that do cite a source do not consistently associate particular requirements with a particular justification. ${ }^{95}$ The legitimacy of judicially imposed internal mangement standards thus remains open to question. Second, the specific contours of internal management review remain unclear. ${ }^{96}$ With no guidelines for which requirements should be imposed, courts adhering to internal management review have experimented to an extraordinary degree. ${ }^{97}$

Given the substantiality of the shift in reviewing posture, the absence of a firm legal basis for that shift, and the lack of agreement on the specific elements of the new form of review, it is not surprising that judicial efforts have failed to yield a uniform and consistently enforced set of principles. Nevertheless, this failure leaves the courts in a difficult position vis-a-vis the agencies. Lacking a coherent model to apply and somewhat hesitant, because of the questions of legitimacy, the judiciary is incapable of applying an internal management model with sufficient consistency and clarity to check adequately agency discretion. ${ }^{98}$

\section{B. The Executive Branch}

The executive branch has relied solely on itself to supervise the internal mangement requirements. President Ford's "inflation impact statement" requirement was supervised by the Office of Management and Budget (OMB) and the Council on Wage and Price Stability (COWPS).99 President Garter's regulatory analysis requirement was supervised by OMB, COWPS, and the Regulatory Analysis Review Group (RARG). ${ }^{100}$ Presi-

95. Id.

96. See supra pp. 745-46.

97. See K. DAVIS, supra note 48, §6:1, at 450; DeLong supra note 32, at 283, 290-307; Verkuil, supra note 48, at 288-89; Verkuil, supra note 37, at 244 .

98. It is possible that the passage of time will lessen legitimacy questions and allow courts to agree on a particular model. The magnitude of current problems, however, suggests that the amount of time necessary will be substantial. Furthermore, the Supreme Court's recent denunciation, in Vermont Yankee Nuclear Power Corp. v. National Resources Defense Council, 435 U.S. 519 (1978), of judicial communication concerning the exact elements of the internal management model is likely to further inhibit judicial movement toward consensus.

99. See Exec. Order No. 11,821, § 2, 3 C.F.R. 203 (1975).

100. The Office of Management and Budget (OMB) was charged with "assurling] the effective implementation of [the Executive] Order." See Exec. Order No. 12,044, § 5, 3 C.F.R. 152, 155-56 (1979). OMB, in turn, delegated this authority to the Council on Wage and Price Stability (COWPS), the Regulatory Analysis Review Group (RARG), and the Council of Economic Advisors (CEA). See M. ROSENBERG, supra note 72, at 11; DeMuth, supra note 20, at 16. RARG is an interagency review group, staffed with or advised by people from OMB, CEA, the Environmental Protection Agency, the Office of Science and Technology Policy, the Council on Environmental Quality, the Domestic Policy Staff, and every cabinet department except Defense, State, and Treasury, see DeMuth, supra note 20 at 16; Tolchin, Presidential Power and the Politics of RARG, REGULATION, July-Aug. 1979, at 44, 44-45, though the major forces are COWPS and the CEA. DeMuth, supra note 20, at 16; Tolchin, supra, at 45. 
dent Reagan's Order relies upon OMB for enforcement. ${ }^{101}$ Each of the Executive Orders precludes judicial review of compliance. ${ }^{102}$

History suggests that reliance upon executive branch supervision is misplaced; the executive branch, by itself, seems unable to enforce the requirements. In 1976, a review by OMB and COWPS of compliance with the inflation impact statement (IIS) requirement concluded that "few IIS's were actually prepared, and those by only a small number of agencies." 103 Four years later, when OMB reviewed compliance with Executive Order 12,044 , it concluded that "agencies may be making a 'sham' out of the regulatory analysis requirement."104

One possible cause of the failure of executive branch enforcement in the past was the weakness of the enforcement provisions. Under both President Ford's and President Carter's plans, enforcement efforts were essentially hortatory. President Reagan has made a dramatic attempt to overcome this problem by giving the OMB extensive enforcement powers, including the authority to order that a proposed or existing rule or set of rules be treated as "major," 105 to order that an agency not publish a notice of proposed rulemaking or its preliminary regulatory impact analysis until

101. See Executive Order No. 12,291, §§ 3, 6, 46 Fed. Reg. 13,193, 13,194-96 (1981). OMB's supervision, in turn, is supervised by the Presidential Task Force on Regulatory Relief, which was also created by Executive Order No. 12,291. Id. \$ 6, 46 Fed. Reg. at 13,196. The Task Force is chaired by Vice-President Bush and includes the Director of OMB, the Secretaries of Treasury, Commerce and Labor, the Attorney General, the Chairman of the GEA, and the Assistant to the President for Policy Development. M. ROSENBERG, supra note 72, at 16. OMB orders may be appealed to the Task Force, Exec. Order No. 12,291, §§ 3(e)(1), 6(a)(1), 46 Fed. Reg. 13,193, 13,194, 13,196, but OMB provides most of the staff support for the Task Force. M. ROSENBERG, supra note 72, at 16.

102. See In re Surface Mining Litig., 627 F.2d 1346, 1357 (D.C. Gir. 1980) (holding that requirements of Executive Order 11,821 were not judicially reviewable); Independent Meat Packers Ass'n v. Butz, 526 F.2d 228, 234-36 (8th Cir. 1975), cert. denied, 424 U.S. 966 (1976) (same); Exec. Order No. 12,291, § 9, 46 Fed. Reg. 13,193, 13,198 (1981); Exec. Order No. 12,044, § 7, 3 C.F.R. 152, 156 (1979). It may be that Presidents Ford, Carter, and Reagan could not have mandated judicial review even had they wanted to. See Independent Meat Packers Ass'n v. Butz, 526 F.2d 228, 234-36 (8th Cir. 1975), cert. denied, 424 U.S. 966 (1976). But cf. In re Surface Mining Regulation Litig., 452 F. Supp. 327, 334 (D.D.C. 1978), modified, 627 F.2d 1346 (D.C. Cir. 1980) (mem. opinion) (implying, in dicta, that court might review compliance with internal rules promulgated by agency to implement Exec. Order No. 11,821).

103. COUNCIL ON WAGE AND PRICE STABILITY \& OFFICE OF MANAGEMENT AND BUdGET, AN EVALUATION OF THE INFLATION IMPACT STATEMENT PROGRAM 79 (1976); see UNITED STATES REGULATORY COUNGIL, A SURVEY OF TEN AGENCIES' EXPERIENCE WITH REGULATORY ANALYSIS (1981) (working paper).

104. OFFICE of MANAGEMENT AND Budget, Improving GovernMent REgulations: A Pro. GRESS REPORT 18 (1980) [hereinafter cited as OMB REPORT]; see Miller, Lessons of the Economic Impact Statement Program, REgulation, July-Aug. 1977, at 14, 16. OMB also found that no agency had a "departmentwide continuously successful effort in place." OMB REPORT, supra, at 18. It is interesting to note that this failure occurred despite President Carter's intense interest in the success of the program. Tolchin, supra note 100 , at 45 . Indeed, Carter demanded that he be given a progress report on the program fortnightly. Id.

105. Exec. Order No. 12,291, § 6(a)(1), 46 Fed. Reg. 13,193, 13,196 (1981). In addition OMB is to prescribe criteria to guide agency determinations of whether rules are major. Id. $\S \S 3(\mathrm{~b}), 6(\mathrm{a})(2)$, 46 Fed. Reg. at 13,194, 13,196. 
OMB's review of the proposed rule is completed, ${ }^{106}$ to order that an agency not publish a final rule or its regulatory impact analysis until the agency has responded to OMB's view concerning the rule or analysis, ${ }^{107}$ and to require an agency to obtain and evaluate additional data. ${ }^{108}$

The Reagan attempt suffers from several defects, however. First, Reagan's assumption, through the $\mathrm{OMB}$, of authority over agency rulemaking appears to be illegitimate. The power assumed allows the White House to exert substantial direct control over agency policy. ${ }^{109}$ This displacement of the discretion vested by Congress in executive branch agencies may violate the Administrative Procedure Act, the statutes granting discretion to agencies, and the separation of powers. ${ }^{110}$ Furthermore, by establishing OMB as a clearinghouse for all regulations, Executive Order 12,291 encourages informal contacts between OMB and the agencies and creates a critical access point to agency decisionmaking. ${ }^{111}$ It thereby creates an environment that may violate strictures concerning ex parte comments in two ways: by allowing ex parte comments by the White House, ${ }^{112}$ and by allowing interest groups to influence agency action by communicating through OMB. ${ }^{113}$

106. Id. § 3(§)(1), 46 Fed. Reg. at 13,195 .

107. Id. $\S 3(f(2), 46$ Fed. Reg. at 13,195 . The agency need not obey OMB's order to refrain from publishing either a notice of proposed rulemaking and preliminary regulatory impact analysis or a final rule and final regulatory impact analysis if obeying the order would conflict with statutorily or judicially imposed deadlines. Id. $\S 8(\mathrm{a})(2), 46 \mathrm{Fed}$. Reg. at 13,198; $c$. id. $\S 8(\mathrm{a})(1), 46 \mathrm{Fed}$. Reg. at 13,198 (no procedure of Executive Order need be followed for regulation responding to emergency situation).

108. Id. § 6(a)(3), 46 Fed. Reg. at 13,196.

109. The illegitimacy of Presidential attempts to guide agency policy has been discussed by many leading judicial figures and commentators. See, e.g., H. FRIENDLY, THE FEDERAL ADMINISTRATIVE AGENCIES 147-63 (1962); J. LANDIS, REPORT ON REGULATORY AGENCIES TO THE PRESIDENT ELECT 207-09 (1960); Verkuil, Jawboning Administrative Agencies: Ex Parte Contacts by the White House, 80 CoLUM. L. REv. 943 (1980).

110. See M. ROSENBERG, supra note 72, at 49-80; Fleishman \& Aufses, Law and Orders: The Problem of Presidential Legislation, LAW \& CONTEMP. PROBS., Summer 1976, at 1; Gewirtz, The Courts, Congress and Executive Policy-Making: Notes on Three Doctrines, LaW \& CONTEMP. PROBS., Summer 1976, at 46, 46-80 (1976); Verkuil, supra note 109, at 950; Note, Delegation and Regulatory Reform: Letting the President Change the Rules, 89 YALE L.J. 561, $577-78$ (1980).

111. See M. ROSENBERG, supra note 72, at 48-80; Bruff, Presidential Power and Administrative Rulemaking, 88 YALE L.J. 451, 466-67 (1979); Tolchin, supra note 100, at 46; Verkuil, supra note 109, at 948-52 (citing R. NEUSTADT, REGULATORY REFORM-THE PRESIDENT'S PROGRAM (1979)).

112. See M. ROSENBERG, supra note 72 , at $49-80,96-111$; Bruff, supra note 111 , at $466-67$. The scope or, indeed, existence of strictures on ex parte comments by the President is as yet unclear. Nevertheless, it has been persuasively argued that ex parte contacts such as those that are encouraged by the Reagan Executive Order would be illegal, as frustrating congressional purposes behind the Administrative Procedure Act or congressional statutes delegating authority to agencies, and perhaps unconstitutional, as violative of the separation of powers. See M. ROSENBERG, supra note 72, at 49-80, 96-111; Verkuil, supra note 109, at 949-50. But see Bruff, supra note 111 (agreeing that certain presidential ex parte comments are illegal or unconstitutional but arguing for a reading of statute and Constitution that arguably might uphold Executive Order 12,291).

113. M. ROSENBERG, supra note 72, at 49-80, 96-111; Bliss, Regulatory Reform: Toward More Balanced and Flexible Federal Agency Regulation, 8 PEPPERDINE L. REV. 619, 634, 637-38 (1981); Bruff, supra note 111, at 466-67; Verkuil, supra note 109, at 950; see also H. FRIENDLY, supra note 
Second, it is not clear that the executive branch is capable of supervising all regulations for compliance. One problem is personnel shortages. Even under the previous Executive Orders staff levels were inadequate; ${ }^{114}$ under President Reagan's Order the staff has been cut ${ }^{115}$ and the responsibilities increased. ${ }^{116}$ Moreover, there are political problems inherent in executive branch self-review. The White House operates in a highly political and public arena. ${ }^{117}$ Because its actions are often viewed as motivated by policy or political concerns, ${ }^{118}$ substantial political pressure is exerted prior to White House actions, and substantial criticisms leveled subsequently. ${ }^{119}$ Because presidential actions are so public, the pressures and criticism are most severe when the President intervenes directly. ${ }^{120}$ The lack of insulation from, indeed, the immersion in, political pressures and criticism makes it likely that the White House also will view its actions in political terms, in terms of how they fit with its major policy objectives or political goals. ${ }^{121}$ The White House will thus tend to stress the political uses of internal mangement requirements rather than their use in ensuring that agency action is "openly informed, reasoned and candid."

There are additional tendencies for executive branch self-review to become politicized. Agencies that are displeased with $\mathrm{OMB}$ review may seek to bring pressure upon OMB to change its actions, either by politicking within the executive branch or by appealing to political supporters outside the executive branch. ${ }^{122}$ The latter course obviously further politicizes the process of review. The former course also has a tendency to politicize, by necessitating presidential intervention to put an end to intrigue and fighting within the executive branch.

Thus, even setting aside the legal and constitutional concerns over the

109, at 153-57 (suggesting that presidency is unlikely to be able to withstand political pressures).

114. See Note, supra note 51, at 1151 (discussing shortage of personnel reviewing President Ford's program); $c f$. Regulatory Action Network: Washington Watch, Sept. 1981, at S-1, col. 1 (discussing inadequacies of current staff).

115. Washington Post, May 4, 1981, § A, at l, col. 4.

116. See Regulatory Action Network: Washington Watch, Sept. 1981, at S-1, col. 1; supra pp. 754-55.

117. See H. FRIENDLY, supra note 109, at 153-54; Bliss, supra note 113, at 634; DeMuth, supra note 20 , at 25 ; Tolchin, supra note 100 , at 49 .

118. See Bliss, supra note 113, at 634, 637; Eads, Harnessing Regulation, REGulation, MayJune 1981, at 19 (suggesting that enforcement of Exec. Order 12,291 will be determined by political concerns); Tolchin, supra note 100 , at 49; N.Y. Times, Nov. 7, 1981, at 28, col. 4 (quoting Rep. Henry A. Waxman's statement that Exec. Order 12,291 will be used as a "political tool rather than as a regulatory tool"); Washington Post, May 4,1981, $\S \mathrm{A}$, at 5 , col. 1 (suggesting same).

119. See DeMuth, supra note 20, at 18-20 (examining operation of Exec. Orders 11,821 and 12,044); Tolchin, supra note 100 , at 49 . 49.

120. See R. NEUSTADT, PRESIDENTIAL POWER 10, 25-32 (1960); Tolchin, supra note 100, at 45,

121. See Bliss, supra note 113 , at $623,634-37$; Tolchin, supra note 100 , at $47,49$.

122. See DeMuth, supra note 20, at 18; Verkuil, supra note 109, at 943, 951-52. 
Executive's use of internal management review as a political weapon, ${ }^{123}$ it is not clear that the executive branch can effectively enforce internal management standards. Even with the best intentions, OMB is likely to be forced into a reviewing posture in which the political desirability of regulations is more important than whether the agency process that promulgated the rule was "openly informed, reasoned and candid."

\section{The Legislative Proposals}

The enforcement provisions of the legislative proposals are varied. Of the two proposals that received the most attention in the 96th Congress, ${ }^{124}$ one relied upon OMB supervision ${ }^{125}$ combined with a legislative veto provision, ${ }^{126}$ while the other merely required the Director of the Congressional Budget Office to monitor compliance. ${ }^{127}$ Of the two proposals receiving the most attention from the 97 th Congress, ${ }^{128}$ one calls for monitoring by $\mathrm{OMB},{ }^{129}$ and the other authorizes the President to establish procedures for agency compliance with the requirements. ${ }^{130}$

None of these proposals mandate judicial review of the internal management requirements. One major proposal from the 96th Congress, S. 262 , flatly precluded judicial review ${ }^{131}$ The other major proposal of the 96th Congress, H.R. 3263, precluded judicial review but called for inclusion of the regulatory analysis in the record, allowing the courts to "consider" it in determining the validity of the rule. ${ }^{132}$ The committee report

123. See Eads, supra note 118, at 19 (suggesting that OMB will be "sharpshooter" taking aim only at politically undesirable regulation); Washington Post, May 4, 1981, § A, at 5, col. 1 (suggesting that enforcement will embody a "one-sided extension of Republican sympathy for business").

124. See supra note 74 .

125. H.R. 3263, supra note $74, \S 101$ (a) (proposed $\S 606$ ) (instructing the Director of OMB to "monitor and review" compliance and to "establish such procedures as may be necessary to ensure compliance"). In addition, the Comptroller General of the United States was to monitor compliance and report to Congress. Id. (proposed $\S 607$ ).

126. Id. $\S 201(\mathrm{~b})(1)$ (proposed $\S 553(\mathrm{~h})(3))$.

127. S. 262 , supra note $74, \S 102$ (proposed $\S 606$ ).

128. See supra pp. 749-50.

129. H.R. 746, supra note 76, $\S 101$ (b) (proposed $\S 624$ ) (requiring that agency submit copy of rule together with description of agency compliance with provisions of the bill to $O M B$, and that $\mathrm{OMB}$ report to President and Congress on degree of compliance with bill by agencies). The Comptroller General is to monitor compliance as well. Id. (proposed \$ 625). In addition, the President or a designee of the President within the executive branch may designate a rule as a "major rule." Id. (proposed $\$ 621(3))$. See supra note 78.

130. S. 1080 , supra note 76, § 4(a) (proposed $\S 624$ ). The President may delegate the authority to an officer within the Executive Office appointed with the advice and consent of the Senate. Id. (proposed $\S 624)$. The President or the person selected under proposed $\S 624$ may designate a rule as a major rule. Id. (proposed $\S 622$ ). See supra note 78.

131. See S. 262, supra note 74, $\S 102$ (proposed $\S 607$ ).

132. H.R. 3263, supra note $74, \S 101$ (a) (proposed $\S 604$ ) states:

(a) Except as otherwise provided in this chapter, any determination by an agency concerning the applicability of any of the provisions of this chapter to any action of the agency, including any determination that a le is not a major rule, shall not be subject to judicial review.

(b) Any regulatory analysis prepared pursuant to section 602 and the compliance or non- 
explained that this preclusion-yet-inclusion mandate was designed to allow the court to read the analysis for background information, but to prohibit review of the performance and conclusions of the analysis. The adequacy of the regulatory analysis was to be, in itself, irrelevant to the determination of whether a court should uphold the rule. ${ }^{133}$

Both of the proposals that have received substantial attention during the 97th Congress follow H.R. 3263 and contain preclusion-yet-inclusion provisions. The relevant language of H.R. 746 is virtually identical to the language of H.R. 3263.134 The language of S. 1080 differs slightly, and is somewhat easier to construe as mandating judicial review. ${ }^{135}$ But the far

compliance of the agency with the provisions of this chapter in preparing and adopting the analysis shall not be subject to judicial review, except that the contents of the regulatory analysis shall, to the extent relevant, be considered by a court when determining the validity of the rule which is the subject of the regulatory analysis. When an action for judicial review of a rule is instituted, any regulatory analysis prepared with respect to such rule shall constitute part of the whole rulemaking record of agency action in connection with such review.

(c) Nothing in this section bars judicial review of any other impact statement or similar analysis required by any other law if judicial review of such statement or analysis is otherwise provided by law.

133.

[S]ection 604 prohibits judicial review of the regulatory analysis itself. This includes the designation of a rule as a major rule or not as a major rule; an agency decision to perform or not to perform a regulatory analysis; the nature or contents of such analysis; or the sufficiency of conclusions of the analysis. The section expressly precludes a court from second-guessing either the process or the conclusions of the analysis.

H.R. REP. NO. 1393, supra note 88 , at 43 . The inclusion of the regulatory analysis in the record is mandated solely because it

may be helpful to the court in understanding the context and nature of the agency's actions. ... [I]f the record itself or the statement of basis and purpose accompanying the rule are devoid of any justification for the rule, a court would be expected to reverse the agency's action, regardless of what is contained in the regulatory analysis. The analyses may indicate what the agency thinks the regulation means or how it is intended to work. If the analyses are patently inconsistent with the agency's explanation of the rule itself, the court may well ask whether the agency has provided a reasoned explanation for its action in adopting the rule. But again, the court must base its decision on the rule itself, the record, and the statement of basis and purpose, not on the contents or conclusions of the regulatory analysis.

Id. (emphasis added).

Similar sentiments were expressed by a member of the Carter Administration, which drafted H.R. 3263 and its identical Senate counterpart, S. 755, see Neustadt, supra note 71 , at 149 , and by the Senator who introduced S. 262 and S. 755, see Ribicoff, For Effectiveness and Efficiency: $S .262$, REGULATION, May-June, 1979, at 17, 18-19. Observers have generally interpreted the provisions in accord with the intentions expressed in the committee report. See, e.g., Senate Hearings, supra note 74, pt. 1, at 441, 445 (statement of Susan B. King, Chairman, United States Consumer Product Safety Commission); Gellhorn, Reform as Totem-A Skeptical View, REgulation, May-June, 1979, at 23, 24. But see Speech by Judge Harold Leventhal in Proceedings of the National Conference on Federal Regulation: The Road to Reform, 32 AD. L. REV. 289, 293 (1980) (stating belief that courts will ignore preclusion provision).

134. See H.R. 746, supra note 76, $\S 101$ (b) (proposed $\S 623$ ). Cf. supra note 132 (relevant language of H.R. 3263).

135. Judicial review

(a) Compliance or noncompliance by an agency with the provisions of this subchapter shall not be subject to judicial review except according to the provisions of this section.

(b) Any determination by the President or by the officer selected under section 624 of this title that a rule is a major rule within the meaning of section $621(4)(\mathrm{A})$ of this title, and any designation by the President or the officer selected under section 624 of this title that a rule is a 


\section{Informal Rulemaking}

greater explicitness of several provisions of S. 1080 that clearly intend judicial review-one allowing a court to strike down an agency determination that a proposed rule is not "major," one allowing review of compliance with certain procedures concerning particpation, and one requiring the agency to maintain a rulemaking file-argues against that construction. ${ }^{136}$

Without explicit provision for judicial review, congressional efforts will face the same enforcement difficulties that executive attempts have faced. ${ }^{137}$ The addition of a legislative veto provision, given its possible unconstitutionality and the inability of an overburdened Congress to monitor more than a few rules, is not likely to cure the problem. ${ }^{138}$

\section{A Proposed Solution: Legislative Endorsement of Judicial Imposi- tion of the Internal Management Model}

The analysis above suggests that each branch, acting by itself, is likely to encounter substantial difficulty in imposing internal management standards upon agencies. This Note suggests one possible means of coordinating efforts: legislative endorsement of judicial review of the internal management requirements.

major rule under section $621(4)(B)$ of this title shall not be subject to judicial review in any manner. . . .

(d) Any regulatory analysis prepared under section 622 of this title shall not be subject to judicial consideration separate or apart from review of the rule to which it relates. When an action for judicial review of a rule is instituted, any regulatory analysis for such rule shall constitute part of the whole rule making record of agency action for the purpose of judicial review of the rule and shall, to the extent relevant, be considered by a court in determining the legality of the rule.

S. 1080 , supra note $76, \S 4($ a) (proposed $\S 623$ ).

136. The provision concerning review of determinations that a rule is or is not "major" states:

The determination of an agency of whether a rule is or is not a major rule within the meaning of section 621 (4)(A) of this title shall be set aside by a reviewing court only upon a clear and convincing showing that the determination is erroneous in light of the information available to the agency at the time it made the determination. Any designation by an agency that a rule is a major rule under section $621(4)(B)$ of this title shall not be subject to judicial review in any manner.

S. 1080 , supra note $76, \S 4$ (a) (proposed $623(\mathrm{c})$ ).

The provision concerning review of procedures as to participation begins: "No court shall hold unlawful or set aside an agency rule because of a failure by the agency to use a particular procedure pursuant to [the relevant subsection] unless . . . Id. $\S 3$ (proposed $\S 553(\mathrm{c})(3)(\mathrm{B})$ ).

The provision concerning review of whether the agency has maintained a rulemaking file, and made it available to the public, was added as a floor amendment; it begins with the same terminology as the provision concerning review of procedures as to participation. See 128 CONG. REC. S2702, S2707 (1982) (floor amendment to S. 1080, supra note 76 ).

137. See supra pp. 754-57.

138. See supra notes $19-20$. 


\section{A. The Benefits of Legislatively-Endorsed Judicial Review of Internal Management Requirements}

The similarities between the purposes and most of the specific requirements of the Executive Orders and legislative proposals, on the one hand, and the evolving judicial response to the problem of administrative discretion, on the other, suggest that review of the internal management requirements is a task for which courts have ample competence and experience. Thus, judicial review can be a powerful force in ensuring that legislatively imposed internal management requirements are fulfilled. Viewed from another perspective, legislative endorsement of judicial review, by defining a set of requirements that the judiciary would legitimately impose upon agencies, would eliminate the problems of legitimacy and consistency that have thus far hindered judicial efforts to control agency discretion through internal management review.

This second perspective also suggests significant "spill-over" benefits from legislative endorsement. In detailing a set of requirements for "major" rules, the legislative proposals also set the starting place for agency and court consideration of non-major rules. They thus increase the possibility that judicially imposed requirements for non-major rules will be reasonably consistent among courts, and that agencies will be able to anticipate those requirements.

It therefore appears that significant benefits can result from judicial review of legislatively specified internal management requirements. It should be noted, however, that some of the requirements of legislative proposals are not internal management requirements but rather are substantive mandates to agencies. As was noted above, the proposals require a determination of whether a proposed rule is major. ${ }^{139}$ In addition, both President Reagan's Executive Order and proposed S. 1080 require that an agency, before it issues a rule, determine that the benefits of a proposed rule outweigh its costs and that the proposal is the most cost-effective alternative legally available to the agency. ${ }^{140}$ Judicial review of these provisions thus cannot be endorsed based on the above analysis alone. Direct review of these provisions would entail substantive determinations rather than the validation of procedural propriety for which courts are most competent and experienced. ${ }^{141}$

139. See supra note 78 .

140. See S. 1080, supra note 76, § 4(a) (proposed § 622(d)(2)(B)); Exec. Order No. 12,291, $\S$ 2(b)-(e), 46 Fed. Reg. 13,193, 13,193 (1981).

141. See supra pp. 743-45.

While this Note's analysis thus cannot be viewed as suggesting the desirability of judicial review of substantive determinations, other arguments in favor of such review can be made. The problems associated with judicial review of substantive requirements can be partially alleviated, perhaps, through creative judicial action. For example, the courts may be able to limit delay, see infra note 142, by 


\section{B. Objections to Judicial Review}

Two main objections to judicial enforcement of the internal management requirements have been raised. One is that judicial review would substantially delay the promulgtion of rules. ${ }^{142}$ The rules that are subject to challenge under the proposals would, however, be subject to judicial review in any case. No relaxation of standing requirements need accompany a provision for judicial review of internal management requirements. Nor would such a provision create an entirely new cause of action; ${ }^{143}$ the analysis above suggests that judicial review of the legislative requirements would simply invigorate an existing cause of action and make its application more consistent.

Indeed, legislative endorsement of judicial review may actually reduce court-induced delay. Agencies will no longer fail to comply based on a lack of knowledge concerning the requirements, or a belief that they will not be enforced. Greater consistency in judicial review of agency rulemaking should thus result in fewer successful challenges to agency action. Moreover, greater success in the courts will not necessarily be restricted to "major" rules; the beneficial effects of the mechanisms that agencies estab-

summary rejection of all but the strongest challenges to agency determinations of whether a bill is "major." They might also seek to convert review of the substantive questions into a more familiar form by asking whether the agency has set up an internal management system to determine the substantive questions in a way that is "openly informed, reasoned and candid," instead of whether the determination itself is correct. Furthermore, the alternatives to judicial review have their flaws as well. Review by the executive branch may tend to become politicized, see supra p. 756, while no review may lead to agency inaction, see supra note 92.

On the other hand, strong arguments can be made for OMB review. OMB has more expertise than the courts to deal with the questions that will arise in review of these issues. See supra p. 743. Less delay would be occasioned by OMB review as OMB could be given a limited time in which to approve or disapprove the agency's decision. Indeed, OMB has demonstrated its ability to move quickly. See MATERIALS, supra note 71, at 11 (estimating that OMB review of agency determinations of whether rule was major took, on average, eight days). Most importantly, perhaps, given judicial review of the management requirements, the bulk of the opportunity and hence temptation for illegitimate use of the power to declare rules "major" will be eliminated.

To weigh the relative merits of these arguments would require investigations that are beyond the scope of this Note.

142. The concern may be motivated by a perception of the deleterious effects of delay caused by judicial review of the environmental impact statement (EIS). This Note does not consider whether judicial review of the EIS is desirable; the analogy is inappropriate in relevant parts. First of all, the Act that required the filing of an EIS also substantially lowered the requirements for standing to sue, thus resulting in a substantial expansion of the class of potential plaintiffs. Furthermore, the EIS requirement created an entirely new cause of action. The analysis above suggests, however, that a challenge concerning whether an agency has fulfilled the regulatory analysis requirements does not create an entirely new cause of action, but rather invigorates and makes more consistent an existing cause of action. Finally, the enforcement of the EIS suffers from the same defect that this Note suggests will be cured by judicial review of the requirements, that is, ambiguity concerning the legitimacy of, and proper type and degree of, judicial enforcement.

143. In contrast, judicial review of the substantive provisions would create entirely new causes of action, thus engendering delay. For example, judicial review of agency determinations that a proposed rule is not "major" would give litigants opposing the regulation a new way to challenge the rule and hence delay its promulgation. 
lish to ensure compliance with the internal management standards will undoubtedly spill over to rules not subject to the regulatory analysis requirements. That has, indeed, been the experience of the Environmental Protection Agency (EPA), one of the few agencies to make more than a half-hearted attempt to comply with Executive Order 12,044 and its predecessor. ${ }^{144}$ EPA reports that its attempts to comply with the Executive Orders have resulted in greater court success against challenges to both major and non-major rules. ${ }^{145}$

The second major objection to judicial review of the legislatively mandated internal management requirements is that courts would be a distorting force, demanding something other than what is intended by the regulatory analysis requirements: courts would cause the agency to "write regulatory analyses as legal briefs instead of candid assessments of hard questions on which the data is often shaky," thus hindering the internal management function of regulatory analysis and creating unnecessary delay. ${ }^{146}$ As pointed out above, however, many courts have adopted internal management review because of a recognition of their limited competence and the need for candid assessments; they have thus supplemented weak substantive review with demands for reasoned explanation, candid assessments of uncertainties, and increased participation. Stated in strong form, then, the objection is based on an error: the failure to comprehend that judicial review of internal management standards is not only possible but prevalent. ${ }^{147}$

A more limited form of the argument can be made, however. If Congress orders courts to review compliance with internal management requirements, any failure of an agency to comply fully with all aspects of

144. OMB REPORT, supra note 104, at A-80.

145. Speech by Douglas A. Costle in Proceedings of the National Conference on Federal Regulation: The Roads to Reform, 32 AD. L. REV. 256, 256 (1980) ("IJ]udicial review has also been a major influence [in EPA's decision to follow the regulatory analysis requirement]. Indeed, one of the key motivating factors behind regulatory analysis at EPA is the realization that our rules must be able to sustain the scrutiny of judicial review."); speech by Joan Bernstein in Proceedings of the National Conference on Federal Regulation: The Roads to Reform, 32 AD. L. REV. 315, 315-16 (1980) (internal management requirements do not cause delay if consistently implemented).

146. Neustadt, supra note 71 , at 149 ; see H. R. REP. NO. 1393 , supra note 88 , at 43 ; Senate Hearings, supra note 74, pt. 1, at 206 (statement of Charles L. Schultze, Chairman, Council of Economic Advisors).

147. This failure to understand that internal management review is feasible and prevalent is perhaps best illustrated by one critic's expression of his understanding of the function of judicial review. Charles Schultze, the then-Chairman of the Council of Economic Advisors that wrote S. 755, expressed his opposition to judicial review of regulatory analysis as follows:

The key function of the federal courts in reviewing administrative action is to evaluate the substantive validity of decisions and to assure that individual rights have been respected in the decision process. The court's function is not to second-guess internal mangement arrangements or processes.

Senate Hearings, supra note 74 , pt. 1, at 226. Schultze is far from alone in failing to perceive the changes in the form of judicial review over the last decade. See DeLong, supra note 32, at 338-39. 
the requirements may result in an attempt to strike down the rule. Thus, though internal management review has been developed, not as an end in itself, but as a means of ensuring that agencies be "openly informed, reasoned and candid," pressure will be brought upon courts to demand a formalistic touching of all bases instead of compliance with the purposes of the requirements. Though plausible, this argument only points out the need for judicial interpretation sensitive to intent rather than form, and for careful drafting of the legislative authorization of judicial review. It does not justify the preclusion of review.

\section{Implications for Legislative Drafting and Judicial Interpretation}

Legislatively endorsed judicial review of legislatively prescribed internal management requirements can yield significant benefits, then, if implemented by the legislature and the judiciary with proper care and attention to the pitfalls. The legislature must recognize that court review of internal management requirements is desirable, but distinguish those aspects of regulatory analysis that do not fit the internal management pattern. Specifically, judicial review of agency determinations that a rule is major and that the benefits of the rule exceed its costs must be justified, if at all, on a different basis than judicial review of internal management requirements for adequate notice, opportunity to participate, and explication. ${ }^{148}$

In addition, the legislature must endorse judicial review in a way that is sufficiently unambiguous to avoid doubt that the courts will enforce the requirements and that such enforcement is legitimate. The courts should be clearly empowered to strike down rules that do not comply with the internal management requirements. ${ }^{149}$ At the same time, however, the legislature must avoid encouraging formalistic review..$^{150}$

There is a tension between the last two requirements, a tension that makes drafting the judicial review provision of the proposed statutes diffcult. Any provision that clearly orders courts to review the requirements opens the door for formalistic review; contrapositively, a provision that is designed to avoid formalistic review will leave some ambiguity concerning the extent and legitimacy of court review. The need for a clear signal to agencies that the requirements will be enforced, along with the importance of legitimating the judicial role, suggests that the legislature should err on the side of a clear mandate for judicial review. However the balance is struck, courts should interpret their mandate in a way that is consonant with the purposes of the requirements and that avoids undue em-

148. See supra note 141 .

149. Without this mandate it will be difficult for courts to avoid the problems they are currently facing. See supra pp. 752-53.

150. See supra pp. 762-63. 
phasis on form.

From this perspective, the judicial review provisions of the major proposals of the 96th and 97th Congresses seem to be far from optimal. The flat preclusion of judicial review contained in S. 262 is obviously inadequate. The provisions of H.R. 3263 and H.R. 746 that preclude review and yet call for inclusion of the regulatory analyses in the record contain undesirable ambiguity, especially when read in conjunction with the associated committee documents. The provisions of S. 1080 are perhaps most subject to attack. S. 1080 clearly mandates direct review of the determination that a bill is not major, a type of review for which courts are less competent and which is far more likely to occasion delay than review of the internal management requirements, and yet leaves ambiguous the courts' role in reviewing the internal management requirements.

If an ambiguous provision is enacted into law, the weight will fall upon the courts to secure the benefits of proper judicial review. Courts can and should interpret the ambiguous provisions as allowing them to strike down a rule for failure to comply substantially with the internal management requirements of the statute. ${ }^{151}$ The more desirable alternative, however, is a clear legislative mandate to that effect.

\section{Conclusion}

Legislative endorsement of judicial review of internal management requirements can be a powerful force in creating agency action that is more "openly informed, reasoned and candid." By making the agency-court relationship more understandable and consistent, it can ameliorate distrust and illegitimacy on the part of both parties. Achieving these benefits, however, requires proper drafting and proper judicial interpretation of the authorizing statute. Current proposals should be amended clearly to authorize the courts to strike down rules for failure to comply with the internal management requirements. With such authorization, courts should measure compliance against the purposes of regulatory analysis and withstand the demands of private litigants for formalistic review. If ambiguous provisions are enacted, the courts should interpret them as permitting judicial review for substantial compliance.

151. Cf. Ackerman \& Hassler, Beyond the New Deal: Coal and The Clean Air Act, 89 YALE L.J. 1466, 1559-61 (1980) (urging courts to adopt principle of "textual priority," ignoring language of committee reports, in reading agency-forcing statutes). 